\title{
Probleme Dayalı Öğrenme Yaklaşımının Öğrencilerin Fen Derslerine Yönelik Tutumlarına Etkisi: Bir Meta-Analiz Çalışması
}

Mehmet Fatih AYAZ*

\section{$\ddot{O ̈ z}$}

$\mathrm{Bu}$ araştırmada probleme dayalı öğrenme (PDÖ) yaklaşımının, öğrencilerin fen derslerine yönelik tutumlarına etkisini belirlemek amacıyla bir meta-analiz çalışması yapılmıştır. Bunun için Türkiye'de yapılmış çalışmalarla ilgili literatür taraması yapılmıştır. 2003-2013 yılları arasında yapılmış, araştırma problemine uygun ve meta-analiz çalışmasına dâhil edilebilecek istatistiksel verilere sahip yüksek lisans tezi ve doktora tezi ulusal veri tabanlarından taranarak incelenmiştir. Literatür taraması sonucunda PDÖ yaklaşımının, öğrencilerin fen derslerine yönelik tutumlarına etkisine ilişkin toplam 18 araştırma çalışmaya dâhil edilmiştir.

Meta-analiz sonucunda PDÖ yaklaşımının, geleneksel öğretim yöntemlerine göre öğrencilerin fen derslerine yönelik tutumlarına pozitif etkisi olduğu belirlenmiştir. PDÖ yaklaşımının öğrencilerin fen derslerine yönelik tutumlarına ilişkin genel etki büyüklüğü değeri 0,711 (\%95 CI, $\mathrm{SE}=0,200)$ olarak belirlenmiştir. Bu değer, Cohen ve arkadaşlarının (2007) etki büyüklüğü sınıflandırmasına göre orta düzeyde bir etki düzeyindedir.

PDÖ yaklaşımının uygulandığı fen bilimleri alanlarında en büyük etki büyüklüğü değerinin kimya alanında olduğu belirlenmiştir. Öğrenim düzeylerinde etki büyüklügü en yüksek üniversite düzeyinde çıkmıştır. Yayın türlerine göre etki büyüklüğü en yüksek doktora tezlerinde çıkmıştır. Çalışmanın son bölümünde, araştırmada elde edilen sonuçlara göre uygulayıcılara, program geliştiricilere ve araştırmacılara önerilerde bulunulmuştur.

Anahtar Kelimeler: Etki Büyüklüğü, Fen, Meta-Analiz, Probleme Dayalı Öğrenme, Tutum.

* Arş. Gör. Dr., Dicle Üniversitesi Ziya Gökalp Eğitim Fakültesi Eğitim Bilimleri Bölümü, mf_ayaz@hotmail.com 


\title{
The Effect of the Problem-Based Learning Approach on the Attitudes of the Students Towards Science Lesson: A Study of Meta-Analysis
}

\begin{abstract}
In this research, the study of the meta-analysis is made to identify that the problem-based learning approach affects the attitudes of the students towards science lesson. Therefore, a literature review is made about studies which are in Turkey. Master's theses and doctoral dissertations (between 2003 and 2013), which are suitable for research problem and have statistical data about the study of the meta-analysis are analyzed by scanning from national database. There are 18 studies, included in the sample, about the effects of the problem-based learning on attitudes of students towards science lesson.

The result of the meta-analysis shows that the problem-based learning approach is more effective than traditional teaching methods about the attitudes of the students towards science lesson. The effect rate of the problem-based learning approach is $0,711(\% 95 \mathrm{CI}, \mathrm{SE}=0,200)$ about students' attitudes towards science lesson. This rate is moderate level beyond to Cohen's and his friends' classification of the effect size (2007).

It is identified that in the field of science, the application of the problem-based learning approach's the greatest effect is on chemistry. It is related that in the level of education it's the greatest effect is on the university level. According to the effect size for the type of publication it's the greatest effect is on doctoral dissertations. At the end of the study; according to the results of the research, there are some suggestions for researchers and instructors.
\end{abstract}

Keywords: Effect Size, Science, Meta-analysis, Problem-based Learning, Attitude.

\section{Giriş}

Bilgi çağının en önemli hedeflerinden biri sorgulayan, bütün dünyaya ve yeniliklere açık bireyler yetiştirmektir. Öğrenmeyi öğrenme, eleştirel düşünme, başkaları ile işbirliği içinde çalışma, bilgi teknolojilerinden yararlanma, bu değişim sürecinde bireyler için önem kazanmıştır. $\mathrm{Bu}$ nedenle eğitim programları kapsamındaki öğretim alanlarının bilimsel, teknolojik ve sistematik yönden başarılı bir biçimde öğretilmesi gerekmektedir. Bir toplumun çağdaş toplumlar düzeyine ulaşması için bilgilerin, inançların ve duyguların bireylere doğrudan 
aktarılması artık yeterli olmamaktadır. Eğitimdeki bu çağdaş yapılanma, araştırmacı öğretimi geliştirmekle gerçekleştirilebilir (Gökmen, 2003: 2).

Bilim ve teknolojideki gelişmeler, Türkiye'de sosyal, siyasal, ekonomik ve kültürel sistemlerin hızlı bir şekilde değişmelerine neden olmaktadır (Ünal, 2005: 26). Buna dayalı olarak toplumsal gelişmenin temel kaynaklarından olan bireylerin değişen bu ihtiyaç ve beklentilere cevap verebilecek niteliklerle yetiştirilmesi gerekmektedir. Bu ihtiyaç gereği günümüzde bireylerden, bilgi tüketmekten çok bilgi üretmeleri beklenmektedir (Kemertaş, 2003: 46). Bilgiye ulaşabilen, ekip çalışması yapabilen insan modeli günümüzde daha çok tercih edilmektedir (Gündoğdu, 2013: 8). Günümüzde bireylerden beklenen yeterlikler; bilgiye ulaşabilme, bilgiyi değerlendirebilme, bilgiyi etkili olarak kullanabilme olarak belirtilmekte; bilgi okur-yazarı olan bireyler istenmektedir (Erdem ve Akkoyunlu, 2002: 3). Bunu gerçekleştirebilmenin tek etkili yolu ise eğitimdir (Soylu, 2004: 55).

Geleceğin dünyasının gereksinimlerinin karşılanabilmesi amacıyla, 2002 yılından itibaren Talim Terbiye Kurulu Başkanlığı tarafından ilköğretim ve ortaöğretim programlarının yenilenmesi çalışmaları yürütülmektedir. $\mathrm{Bu}$ bağlamda Milli Eğitim Bakanlığı, öğretim programlarını yeniden düzenlemiş ve 2004 yılı itibariyle birçok farklı öğrenme yaklaşımı ve modeli eğitim-öğretim sürecine dâhil olmuştur. Bunların en önemlilerinden biri de probleme dayalı öğrenme (PDÖ) yaklaşımıdır. Son yıllarda, bireylerin kendi öğrenmelerinde aktif rol almaları üzerinde özellikle durulmaktadır. Öğrenme ve öğretme süreçlerinin doğasını açılamaya yönelik olan PDÖ yaklaşımı birçok fen eğitimcisi tarafından desteklenmektedir (Staver ve Shroyer, 2002).

PDÖ yaklaşımı ilkeler açısından en fazla yapısalcı kurama dayanmaktadır. Yapısalcı kuram öncelikle bir öğrenme kuramıdır. Yapısalcı kuram Dewey ve Piaget'in çalışmaları doğrultusunda ortaya çıkmıştır (Bayrak, 2007). PDÖ, öğrencilerin öncelikle öğretmenler ve ders kitaplarından öğrenmelerinden daha çok, gruplar halinde ve kendi kendilerine gerçek dünya problemlerinin çözümü için araştırma yapmalarını sağlayan bir öğrenme yaklaşımıdır (Sönmez ve Lee, 2003). PDÖ yaklaşımında, ilk önce problem verilir ve bu durum, kavramların bölüm sonu problemlerinden önce verildiği geleneksel öğretime zıttır. Geleneksel sunuma dayalı öğretimde öğrencilerden problemi çözmek için öğretmen tarafından anlatılan bilgiye başvurmaları istenir (Uden ve Beaumont, 2006). 


\section{Araştırmanın Amacı ve Önemi}

Günümüzde bilimsel çalışmaların sayısı hızla artmaktadır. Belirli bir konuda yapılmış, birbirinden bağımsız çalışmalarda birbirinden farklı sonuçlara ulaşılabilmektedir. Çalışmalar kendi başlarına kapsamlı genellemeler yapılacak şekilde tasarlansa da sınırlılıklarıyla birlikte çok kapsamlı açıklamalar veremezler ve çalışılan konuda daha fazla araştırma yapılması gerçeğini belirterek sonuçlanırlar (Özcan, 2008: 4).

Eğitim bilimlerinin kendi doğası gereği, araştırmalarda olay ve olgular kendi ortamları içinde incelenmektedir. Araştırmacı, kendi ortamı içinde olan olay ve olguları derinlemesine açıklamaya ve yorumlamaya çalışmaktadır (Yıldırım ve Şimşek, 2011: 239). Yapılan araştırmalarda, problemlere somut çözümler getirene kadar araştırma çabalarının sürdürülemediği görülmektedir (Karasar, 2005: 23). Oluşan bilgi birikimini yorumlamak ve yeni çalışmalara yol açmak için, kapsayıcı ve güvenilir nitelikte üst çalışmalara ihtiyaç vardır (Akgöz, Ercan ve Kan, 2004: 107).

Türkiye'de eğitim programları 2005 yılında yapılandırmacı öğrenme yaklaşımı merkeze alınarak yenilenmiştir. Bununla birlikte eğitim-öğretim sürecinde PDÖ yaklaşımının önemi artmış ve bu yaklaşımın önemi birçok araştırmada ortaya konmuştur. Türkiye'de "Probleme Dayalı Öğrenme Yaklaşımı" konusu etrafında yapılmış çok sayıda çalışma mevcuttur (Tavukcu, 2006; Özyalçın Oskay, 2007; Bayrak, 2007; Tatar, 2007; Akın, 2008; İnel, 2009; Kartal Taşoğlu, 2009; Tosun, 2010; Şahbaz, 2010; Moralar, 2012). Bu çalışmalarda genel olarak PDÖ yaklaşımının akademik başarıya, tutuma, bilimsel süreç becerilerine, motivasyona, memnuniyete, eleştirel düşünmeye, algılara vs. etkisi incelenmektedir. Çeşitli açılardan yapılmış PDÖ yaklaşımı konusu araştırmalarının birleştirilmeye, sentezlenmeye ve değerlendirilmeye ihtiyacı vardır.

Öğrencilerin, öğrenmeyi öğrenmesini sağlamak ve akademik başarılarını arttırmak hemen hemen bütün derslerin ortak hedefidir. Akademik başarılarının yanında öğrencilerin duyuşsal yönden geliştirilmesi de öğretim programlarının temel hedefleri arasındadır. Fen (Fen Bilgisi, Fen ve Teknoloji, Fizik, Kimya, Biyoloji) Derslerinin Öğretim Programlarının ortak vizyonu; bireysel farklılıkları ne olursa olsun bütün öğrencilerin fen okuryazarı olarak yetişmesidir. Fen okuryazarlığı, genel bir tanım olarak; bireylerin araştırma-sorgulama, eleştirel düşünme, problem çözme ve karar verme becerileri geliştirmeleri, yaşam boyu öğrenen bireyler olmaları, çevreleri ve dünya hakkındaki merak duygusunu sürdürmeleri için gerekli olan fen bilimleri ile ilgili beceri, tutum, değer, anlayış ve bilgilerin bileşimidir (MEB, 2005: 34). 
Sosyal Bilimler Dergisi 55

Bireylerin fen okuryazarı olarak yetiştirilebilmeleri için fen bilimleri öğretiminin bilimsel araştırmaya dayalı olarak gerçekleştirilmesi gerekmektedir. Bilimsel araştırma yaparken sadece bilimsel bilgi üretmekle kalınmayıp yaşamda bilimsel düşünmek ve bilimsel süreçleri kullanarak bilgiye ulaşma becerilerinin geliştirilmesi ve bilimin yaşanarak öğrenilmesi amaçlanır (Bağcı Kılıç, 2003: 46). Öğrencilerin birer bilim adamı gibi düşünmelerini sağlamak öğrenme sürecinde çok önemlidir (Senemoğlu, 2010: 469). Öğrencilerde bilimsel süreç becerileri, bilgi oluşturmada, problemler üzerinde düşünmede ve sonuçları formüle etmede kullanılan düşünme becerileridir (Topsakal, 2005: 25). Bu nedenle PDÖ yaklaşımı, özellikle fen bilimleri için çok önemlidir.

Özellikle fen bilimleri alanında kullanılan PDÖ yaklaşımının öğrencilerin fen derslerine yönelik tutumlarına etkisini belirlemek amacıyla yapılmış çok sayıda birincil çalışma bulunmaktadır. Bu nedenle, "Probleme dayalı öğrenme yaklaşımının, öğrencilerin fen derslerine yönelik tutumlarına nasıl bir etkisi vardır?" sorusuna cevap bulmak önem kazanmaktadır.

$\mathrm{Bu}$ amaçla aşağıdaki sorulara yanıt aranmaktadır:

1. Probleme dayalı öğrenme yaklaşımı, öğrencilerin fen derslerine yönelik tutumları üzerinde pozitif bir etkiye sahip midir?

2. Probleme dayalı öğrenme yaklaşımı ile ilgili yayınların etki büyüklükleri arasında, çalışmaların yayın türüne (yüksek lisans tezi, doktora tezi) göre öğrencilerin fen derslerine yönelik tutumlarında anlamlı bir farklılık var midır?

3. Probleme dayalı öğrenme yaklaşımı ile ilgili yayınların etki büyüklükleri arasında, öğrencilerin fen bilimleri alanlarına (fizik, kimya, biyoloji) yönelik tutumlarında anlamlı bir farklılık var mıdır?

4. Probleme dayalı öğrenme yaklaşımı ile ilgili yayınların etki büyüklükleri arasında, öğrencilerin öğrenim düzeylerine (ilkokul, ortaokul, lise, üniversite) göre fen derslerine yönelik tutumlarında anlamlı bir farklılık var midır?

5. Probleme dayalı öğrenme yaklaşımı ile ilgili yayınların etki büyüklükleri arasında, çalışmalardaki deney grubunun örneklem büyüklügüune (1-29 öğrenci, 30 ve üstü öğrenci) göre öğrencilerin fen derslerine yönelik tutumlarında anlamlı bir farklılık var mıdır?

6. Probleme dayalı öğrenme yaklaşımı ile ilgili yayınların etki büyüklükleri arasında, çalışmalardaki uygulama süresine (1-19 saat, 20 ve üstü saat) göre öğrencilerin fen derslerine yönelik tutumlarında anlamlı bir farklılık var mıdır? 


\section{Yöntem}

Bu bölümde; çalışmada kullanılan araştırma modeli, verilerin toplanması, dâhil edilme ölçütleri, verilerin kodlanması, verilerin analiz edilmesi ve yorumlanması başlıkları yer almaktadır.

\section{Araştırma Modeli}

Araştırmada PDÖ yaklaşımının etkililiğini belirlemek amacıyla meta-analiz yöntemi kullanılmıştır. Meta-analiz, bilimsel araştırmada bir literatür tarama yöntemidir. Meta-analiz, bireysel çalışmaların sentezlenmesi ve yorumlanması amaciyla kullanılan istatistiksel prosedürler uygulamasıdır. Meta-analiz, bir alanda benzer çalışmaların sonuçlarının birleştirilmesi için kullanılan istatistiksel bir yöntemdir (Ergene, 1999: 34). Bireysel çalışmalardan elde edilmiş deneysel bulguların birleştirilmesini, çok sayıda analiz sonuçlarının bütünleştirilmesini sağlamak için kullanılan istatistiksel analizlerdir (Glass, 1976). Meta-analiz, birçok araştırma sonucunun ortak bir ölçü birimine çevrilerek karşılaştırılmasını ve istatistiksel işlemlerle etki büyüklüklerinin hesaplanmasını sağlamaktadır (Rudy, 2013). Meta-analiz, kısaca diğer analizlerin analizidir. Çalışmaların sonuçlarını tutarlı ve uyumlu bir şekilde bir araya getirir (Cohen ve Manion, 2001: 24).

\section{Verilerin Toplanması}

Araştırmaya dâhil edilecek çalışmalar, 2003-2013 yılları arasında Türkiye'de "Probleme Dayalı Öğrenme Yaklaşımı" ile ilgili yayımlanmış ve yayımlanmamış, araştırma problemine ve gerekli istatistiksel verilere sahip olan yüksek lisans ve doktora tezlerinden oluşmaktadır.

Türkiye'de yapılan lisansüstü tezlerin taraması hem Türkçe hem de İngilizce olarak YÖK Ulusal Tez Merkezi internet sitesinden 23.09.2014 ve 22.12.2014 tarihleri arasında gerçekleştirildi. Taramada, başlığında ve anahtar kelimelerinde Türkçe olarak içinde "probleme dayal öğrenme", "problem temelli öğrenme", İngilizce olarak "problem based learning" kelimeleri olan tezler listelenmiştir. Listeleme sonucunda araştırma sınırları içerisinde kalan 76 adet tez ismine ulaşılmıştır. Dolayısıyla araştırma için toplam 76 adet tez taranmıştır. İncelemeler sonucunda araştırma problemine ve dâhil edilme ölçütlerine uygun tezler çalışmaya dâhil edilmiştir. Kısıtlamalı veya tez merkezinde bulunmayan tezlerin yazıldığ 1 üniversitenin kütüphanesi veya yazarları ile iletişime geçilip istenmiştir. Bu şekilde toplam 2 teze ulaşılmıştır. İnceleme boyunca PDÖ yaklaşımının öğrencilerin fen derslerine yönelik tutumlarına etkisine yönelik, araştırma konusuna uygun 17 adet teze ulaşılmıştır. 
Sosyal Bilimler Dergisi 57

Tutum ile ilgili olarak yayınlanan lisansüstü tezlerden 1 tanesinde 2 farklı çalışma bulunmaktadır. Bu nedenle bu çalışma 2 ayrı çalışma olarak değerlendirilmiş ve meta-analize bu şekilde dâhil edilmiştir.

\section{Dâhil Edilme Ölçütleri}

Araştırmaya dâhil edilen çalışmalar için kullanılan ölçütler şunlardır:

1. Çalışmanın 2003-2013 yılları arasında yapılmış olması.

2. Çalışmanın Türkiye' de yapılmış yüksek lisans tezi, doktora tezi veya bilimsel dergilerde yayımlanmış makale olması.

3. Deneysel çalışmalar olması.

4. Deney grubuna probleme dayalı öğrenme yaklaşımının, kontrol grubuna ise geleneksel öğretim yöntemlerinin uygulanması.

5. Probleme dayalı öğrenme yaklaşımının, öğrencilerin fen derslerine yönelik tutumlarına ilişkin aritmetik ortalama ve standart sapma değerlerinin olması.

6. Çalışılan grupların örneklem büyüklüğünün verilmesi.

\section{Verilerin Kodlanması}

Meta-analizde kodlamaların güvenirliği önemli bir noktadır. Bu nedenle, tüm çalışmaların en az iki uzman tarafından değerlendirilmesi gerekir (Açıkel, 2009; Akçil ve Karaağaoğlu, 2001). Araştırmada çalışmaların meta-analize dâhil edilme ölçütlerine uygun olup olmadığının anlaşılması ve meta-analizde çalışmalar arasında karşılaştırma yapılabilmesi için çalışmanın amacına uygun olarak bir Kodlama Formu (Ek-1) düzenlenmiştir. Kodlama formundaki bilgiler çalışmanın genel özelliklerini belirlemek üzere seçilmiştir. Kodlama formunda bulunan bazı özellikler şunlardır: Çalışmanın adı, çalışmanın yazarı, çalışmanın türü, çalışmanın yayınlandığı yıl, çalışmada kullanılan ölçeğin kim tarafından hazırlandığı, uygulama süresi, çalışmanın uygulandığı il, çalışmanın uygulandığı öğrenci grubunun öğrenim düzeyi, çalışmadaki istatistikî veriler, çalışmanın etki büyüklüğü.

Çalışmanın güvenirliğini sağlamak için, kodlamaların en az iki araştırmacı tarafından ayrı ayrı yapılması önemlidir. Bu çalışmada da kodlamalar iki araştırmacı tarafından yapılmıştır. Birinci ve ikinci araştırmacının analizleri karşılaştırılarak örtüşen ve örtüşmeyen kodlamaların sayısı belirlenmiştir. Kodlamaların güvenirliği, güvenirlik düzeyi formülü (Miles ve Huberman, 2002) kullanılarak \%96 bulunmuştur. $\mathrm{Bu}$ formülden elde edilen \%70 ve üzerinde değerler güvenirlik için yeterli bulunmaktadır. $\mathrm{Bu}$ nedenle kodlamaların güvenilir olduğu söylenebilir. 
Örtüşmeyen kodlamalar, iki araştırmacı tarafından tekrar kontrol edilip ortak kararla düzeltilmiştir.

\section{Verilerin Analizi Ve Yorumlanması}

$\mathrm{Bu}$ çalışmada verilerin analizinde işlem etkisi meta-analizi kullanılmıştır. Glass tarafından geliştirilen bu teknik, eğitim uygulamaları, sosyal bilimler ve psikoloji araştırmalarında çok önemli bir yer tutar. Bu tür meta-analiz, işlem etkisini, bu etkilerin birbirleriyle olan ilişkilerini, öznenin doğası, yapılan işlemin miktarı ve etkisi faktörleri ile özetlemektedir.

İşlem etkisi meta-analizi, "d", "g" veya "ES" harfleriyle gösterilen standartlaştırılmış etki büyüklügünü kullanır. Bu deney grubu ile kontrol grubu ortalamaları arasındaki farkın alınıp toplam standart sapmaya ( $E S=\frac{\bar{X}_{d}-\bar{X}_{k}}{S}$ ) bölünmesi sonucu bulunur. Bu istatistik yöntemi, çoklu çalışmalarda kullanılan bağımsız çalışmaların verilerini ortak bir ölçme sistemine çevirerek, ortaya çıkan etki büyüklüklerinin karşılaştırılmasını sağlar.

Araştırmaya dâhil edilen çalışmalarda kullanılan ölçekler aynı olmadığı ve çalışmalarda aykırı değerlere sahip çalışmalar olabileceği için PTÖ yaklaşımı uygulanmış ve uygulanmamış gruplar arasındaki farklılıkları test etmek için kabul edilebilir standartlarda meta-analiz istatistiğine uyarlanmış örneklem metodu ile tespit edilmiş çalışmalarda standartlaştırılmış aritmetik ortalamalar farkı etki büyüklüğü istatistik yöntemi kullanılmıştır (Wolf, 1986; Cohen, 1988; Hunter ve Schmidt, 1990; Rosenthal, 1991; Lipsey ve Wilson, 2001; Huffcutt, 2002; Schulze, 2004).

Meta-analiz sonucunda elde edilen etki büyüklüklerinin önemini yorumlarken sınıflandırmalar kullanılır. Etki büyüklüğü sınıflandırması Cohen ve diğerlerine göre şu şekildedir (2007: 521):

- $0 \leq$ Etki büyüklüğü değeri $\leq 0,20$ zayıf (poor),

- 0,21 $\leq$ Etki büyüklüğü değeri $\leq 0,50$ küçük (modest),

- $0,51 \leq$ Etki büyüklüğü değeri $\leq 1,00$ orta (moderate),

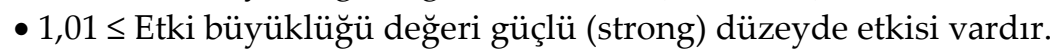

Araştırma konusu hakkında taranan çalışmalar, niteliksel olarak analiz edilerek meta-analize dâhil edilecek çalı̧̧malar belirlenir. Bu aşamadan sonra sonuçların istatistiksel olarak birleştirilmesi gerekmektedir. Meta-analizde etki büyüklükleri hesaplanmadan önce Hedges ve Olkin (1985)'in Q istatistikleri (etki büyüklüklerinin ve evren örneklemlerinin homojenliğini ölçmede kullanılan testler) diye tanımladıkları analiz ile hangi 
Sosyal Bilimler Dergisi 59

istatistiksel modelin kullanılacağına karar verilir. Sabit etkiler ve rastgele etkiler model olmak üzere iki ayrı model vardır.

Sabit etkiler modelinde her çalışmanın ayn etkiye sahip olduğu varsayılır (Borenstein, Hedges, Higgins ve Rothstein, 2009). Bir nedenden dolayı çalışmalar arasındaki etki büyüklükleri farklılık gösterirse buna örneklem hatası denmektedir (Borenstein vd, 2013: 80). Rastgele etkiler modeli çalışmaların etki büyüklüklerinin ortalamasını tahmin eden modeldir (Borenstein vd, 2013: 86). Çalışmaların her birinde çalışmayı etkileyen faktörler büyük ihtimalle farklılık gösterecektir. Bu farklılıkların varlığı önemli ise rastgele etkiler modeli kullanmak daha uygun olacaktır. Rastgele etkiler modeli kullanıldığı zaman alt gruplar içindeki genel etkideki önem, tek çalışmada çalışıldığı zamanki önemle aynıdır (Borenstein vd, 2013: 159)

Q istatistiği ile birlikte çalışmaların heterojenliği ile ilgili başka istatistikler de vardır. $Q$ istatistiğinin bir tamamlayıcısı olarak geliştirilen ${ }^{2}{ }^{\prime}$ nin heterojenliğe ilişkin daha açık bir sonuç verebileceği söylenebilir (Petticrew ve Roberts, 2006: 217). I ${ }^{2}$ sonucu $\% 25$ düşük düzeyde heterojenliği, $\% 50$ orta düzeyde heterojenliği ve $\% 75$ yüksek düzeyde heterojenliği göstermektedir (Cooper, 2010).

Bu meta-analiz çalışmasında PDÖ yaklaşımı ile geleneksel öğrenme yöntemlerinin etkileri karşılaştırılmıştır. Çalışmada, PDÖ yaklaşımı bağımsız değişken, öğrencilerin fen derslerine yönelik tutumlarının etki büyüklükleri bağımlı değişken olarak alınmıştır.

Verilerin analizinde Comprehensive Meta-Analysis (CMA), MetaWin ve SPSS programları kullanılmıştır.

\section{Bulgular}

$\mathrm{Bu}$ bölümde, meta-analize ait bulgular verilmiştir. Araştırmanın problemlerinin meta-analiz yöntemiyle birleştirilmesi sonucu elde edilen analiz sonuçları ile bunların yorumlarına yer verilmiştir.

\section{Genel Etki Büyüklüğü Bulguları}

PDÖ yaklaşımının öğrencilerin fen derslerine yönelik etkisi ile geleneksel öğretim yöntemlerinin öğrencilerin fen derslerine yönelik etkisinin karşılaştırılmasını içeren meta-analiz bulguları aşağıda verilmiştir.

Çalışmaların etki büyüklüklerinin genel dağılımının, $x=y$ doğrusu etrafında ve kesik noktalarla gösterilen güven aralıklarında bulunması etki büyüklüklerinin normal dağılıma uygun olduğunu gösterir. Araştırmaya dâhil edilen çalışmaların etki büyüklüklerinin normal dağılım grafiği Şekil 1 'de verilmiştir. 


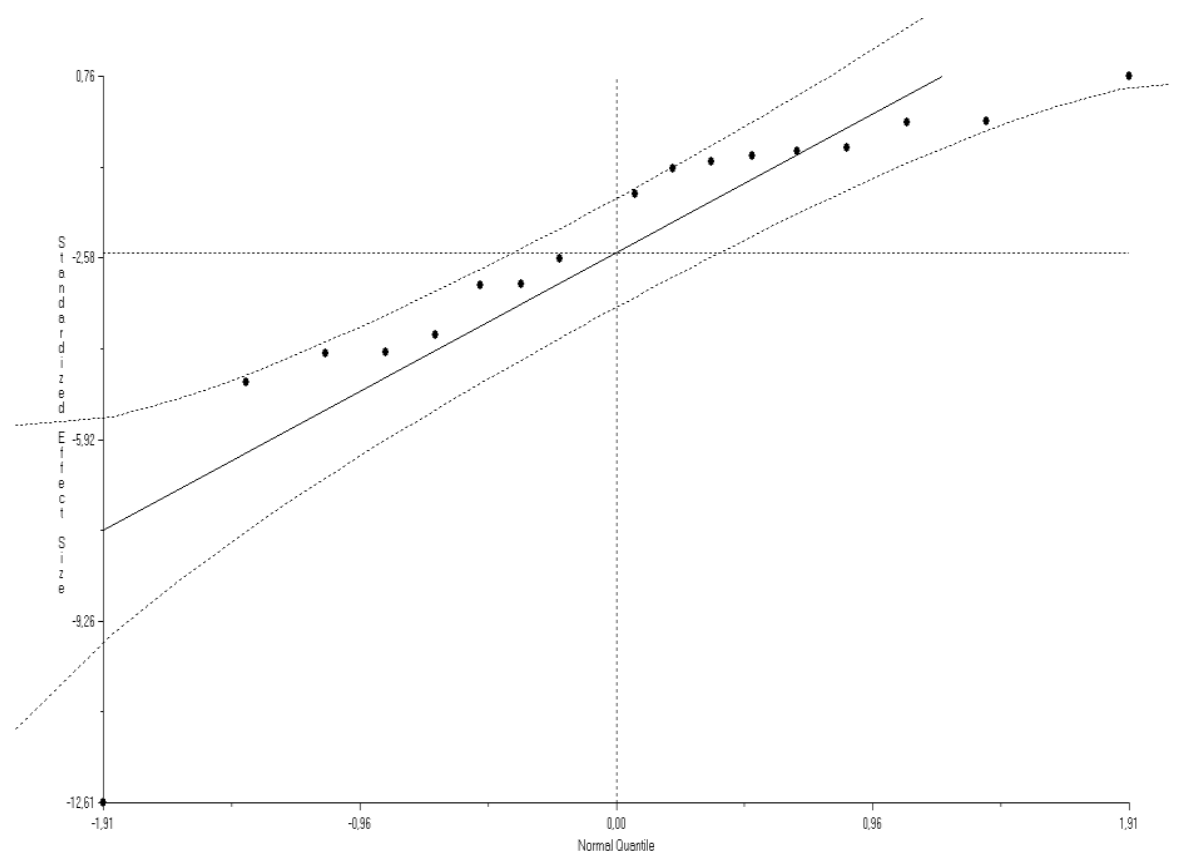

Şekil 1. Etki Büyüklüklerinin Normal Dağılım Grafiği

Çalışmaların etki büyüklüklerinin normal dağılım grafiğine bakıldığında etki büyüklüklerinin normal dağılım doğrusu yakınında oldukları ve belirtilen sınırları aştığı görülmektedir. Bu nedenle araştırmaya dâhil edilen çalışmaların normal dağılım gösterdiği belirlenmiştir.

Çalışmaların etki büyüklüklerini hesaplayabilmek için öncelikle kullanılması gereken meta-analiz modelinin belirlenmesi gerekiyor. Öncelikle sabit etkiler modeli ile çalışmaların homojenliğinin test edilmesi gerekir.

Sabit etkiler modeli ile çalışmaların homojenliğine ve genel etki büyüklüğüne ilişkin bulgular aşağıdaki Tablo 1'de verilmiştir.

Tablo 1. Sabit Etkiler Modeline Göre Çalışmaların Etki Büyüklüklerine Ait Bulgular

\begin{tabular}{|c|c|c|c|c|c|c|c|}
\hline ES & df & Q & $\begin{array}{c}\text { Chi- } \\
\text { Square }\end{array}$ & SE & $I^{2}$ & \multicolumn{2}{|c|}{ ES (\%95 CI) } \\
\cline { 6 - 8 } & & & Min. & Max. \\
\hline 0,672 & 17 & 162,538 & 27,587 & 0,064 & 89,54 & 0,546 & 0,797 \\
\hline
\end{tabular}


Sosyal Bilimler Dergisi 61

Araştırmaya dâhil edilen çalışmaların homojenlik değeri sabit etkiler modeline göre hesaplandığında $\mathrm{Q}=162,538$ bulunmuştur. $\chi^{2}$ tablosundan \%95 anlamlılık düzeyinde on yedi serbestlik derecesi ile kritik değer 27,587 olarak bulunmuştur. Q istatistiksel değeri 162,538 ile on yedi serbestlik derecesindeki ki-kare dağılımının kritik değerini ( $\mathrm{df}=17$ için $\left.\chi^{2}(0,95)=27,587\right)$ aştığ1 görülmüştür. Bu sonuçla çalışmaların etki büyüklüğü değerlerinin sabit etkiler modeline göre heterojen özellikte olduğu belirlenmiştir. Aynı şekilde, $\mathrm{I}^{2}$ değeri \%90'a yakın ile yüksek düzeyde heterojen çıkmıştır. Bu nedenle etki büyüklüğü değerlerinin altında yatan bir tek gerçek etkinin var olması söz konusu değildir.

Sabit etkiler modeline göre çalışmalar heterojen çıktığından rastgele etkiler modeli kullanılarak örneklemin heterojen olmasından kaynaklanan yanılsamalar ortadan kaldırılabilir. Rastgele etkiler modeli ile çalışmaların genel etki büyüklüğüne ilişkin bulgular Tablo 2'de verilmiştir.

Tablo 2. Rastgele Etkiler Modeline Göre Çalışmaların Etki Büyüklüklerine Ait Bulgular

\begin{tabular}{|c|l|c|c|c|c|c|c|}
\hline ES & df & Q & $\begin{array}{c}\text { Chi- } \\
\text { Square }\end{array}$ & SE & I $^{2}$ & \multicolumn{2}{|c|}{ ES (\%95 CI) } \\
\cline { 6 - 8 } & & & & & Min. & Max. \\
\hline 0,711 & 17 & 20,863 & 27,587 & 0,200 & 18,52 & 0,318 & 1,103 \\
\hline
\end{tabular}

Araştırmaya dâhil edilen çalışmaların homojenlik değeri rastgele etkiler modeline göre hesaplandığında $\mathrm{Q}=20,863$ bulunmuştur. $\chi^{2}$ tablosundan \%95 anlamlılık düzeyinde on yedi serbestlik derecesi ile kritik değer 27,587 olarak bulunmuştur. Q istatistiksel değeri 20,863 ile on yedi serbestlik derecesindeki ki-kare dağılımının kritik değerini ( $\mathrm{df}=17$ için $\left.\chi^{2}(0,95)=27,587\right)$ aşmadığı görülmüştür. Ayrıca I² sonucu \%19'a yakın bir sonuçla düşük düzeyde heterojen çıkmıştır. Bu nedenle çalışmaların etki büyüklügü değerlerinin rastgele etkiler modeline göre homojen özellikte olduğu belirlenmiştir. Bu nedenle çalışmaların etki büyüklüğü değerlerinin rastgele etkiler modeline göre homojen özellikte olduğu belirlenmiştir.

Rastgele etkiler modeline göre yapılan analiz sonucunda ortalama etki büyüklügü değeri 0,200 standart hata ile 0,711 olarak bulunmuştur. \%95 güven aralığında etki büyüklügünün alt sınırı 0,318, üst sınırı 1,103 olarak hesaplanmıştır. İstatistiksel anlamlılığa bakıldığında $\mathrm{Z}=3,549$ ve $\mathrm{p}=0,000$ olarak bulunmuştur. Buna göre ulaşılan sonucun istatistiksel olarak anlamlı olduğu söylenebilir.

Ortalama etki büyüklüğü değerinin pozitif çıkması $(+0,711)$, işlem etkisinin deney grubu lehine olduğunu gösterir. $\mathrm{Bu}$ nedenle PDÖ 
yaklaşımının öğrencilerin fen derslerine yönelik tutumlarına etkisinin geleneksel öğretim yöntemlerine göre olumlu yönde daha etkili olduğu söylenebilir. Bu etki Cohen ve arkadaşlarının (2007) sınıflandırmasına göre orta düzeyde bir etkidir. Çalışmaların etki büyüklügü ile ilgili bulgular Şekil 2 'de verilmişti.

\begin{tabular}{|c|c|c|c|c|c|}
\hline \multirow[t]{2}{*}{ Study name } & \multirow[b]{2}{*}{$\begin{array}{l}\text { Std diff } \\
\text { in means }\end{array}$} & \multirow[b]{2}{*}{$\begin{array}{l}\text { Standard } \\
\text { error }\end{array}$} & \multicolumn{3}{|c|}{ Statistics for each study } \\
\hline & & & Variance & $\begin{array}{l}\text { Lower } \\
\text { limit }\end{array}$ & $\begin{array}{l}\text { Upper } \\
\text { limit }\end{array}$ \\
\hline Günep 2006 & 0,200 & 0,284 & 0,080 & $-0,356$ & 0,756 \\
\hline Tavukcu, 2006 & 0,725 & 0,232 & 0,054 & 0,270 & 1,180 \\
\hline Yýldýz, 2012 & 0,128 & 0,227 & 0,051 & $-0,317$ & 0,572 \\
\hline Moralar, 2012 & 0,493 & 0,340 & 0,116 & $-0,174$ & 1,160 \\
\hline Çelik, 2010 & $-0,241$ & 0,310 & 0,096 & $-0,848$ & 0,366 \\
\hline Kanlý, 2008-1 & 0,325 & 0,395 & 0,156 & $-0,448$ & 1,099 \\
\hline Kanlý, 2008-2 & 0,424 & 0,433 & 0,187 & $-0,424$ & 1,273 \\
\hline Palgam, 2009 & 0,016 & 0,232 & 0,054 & $-0,440$ & 0,471 \\
\hline Taboðlu, 2009 & 0,189 & 0,296 & 0,087 & $-0,391$ & 0,768 \\
\hline Oskay, 2007 & 4,089 & 0,324 & 0,105 & 3,455 & 4,724 \\
\hline Bayram, 2010 & 0,364 & 0,255 & 0,065 & $-0,136$ & 0,865 \\
\hline Yýldýrým, 2011 & 0,772 & 0,293 & 0,086 & 0,198 & 1,347 \\
\hline Bayrak, 2007 & 1,023 & 0,233 & 0,055 & 0,566 & 1,481 \\
\hline Tosun, 2010 & 0,767 & 0,248 & 0,061 & 0,281 & 1,252 \\
\hline Benli, 2010 & 0,021 & 0,246 & 0,061 & $-0,461$ & 0,504 \\
\hline Kupdemir, 2010 & 1,226 & 0,302 & 0,091 & 0,634 & 1,819 \\
\hline Korucu, 2007 & 1,279 & 0,293 & 0,086 & 0,704 & 1,854 \\
\hline \multirow{2}{*}{ Yurd, 2007} & 1,052 & 0,215 & 0,046 & 0,632 & 1,473 \\
\hline & 0,711 & 0,200 & 0,040 & 0,318 & 1,103 \\
\hline
\end{tabular}

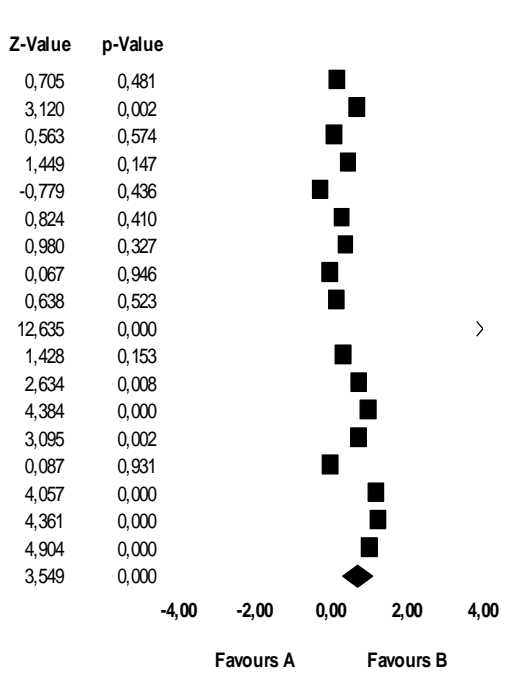

Şekil 2. Çalışmalara Ait Etki Büyüklüğü Değerleri

Grafikte bulunan kareler bulundukları çalışmanın etki büyüklügünü, karelerin iki yanındaki çizgiler \%95 güven aralığında etki büyüklüklerinin alt ve üst limitlerini göstermektedir. Karelerin alanı ait oldukları çalışmaların genel etki büyüklüğü içindeki ağırlığını göstermektedir. Şeklin en aşağısında bulunan eşkenar dörtgen olan elmas çalışmaların genel etki büyüklügüünü göstermektedir.

Çalışmalara ait etki büyüklükleri incelendiğinde en küçük etki büyüklüğü değerinin -0,241, en yüksek etki büyüklüğü değerinin ise 4,089 olduğu belirlenmiştir. Çalışmaların etki büyüklüğü değerlerine bakıldığında 18 çalışmanın 17'si pozitif, 1'i negatif tamamı pozitif etkiye sahiptir. Pozitif etkiye sahip 24 çalışma PDÖ yaklaşımının uygulandığı deney grubu lehine bir etkiye sahiptir.

Meta-analize dâhil edilen çalışmaların etki büyüklüklerine ait bulguların anlamlılığının değişmesi için gerekli olan çalışmaların sayısı Orwin yöntemi ile analiz edilmiştir. Orwin yöntemi ile ortalama etki büyüklüğü sıfır olan çalışma sayısı hesaplanır (Hunter ve Schmidt, 1990; 
Sosyal Bilimler Dergisi 63

Lipsey ve Wilson, 2001). Orwin pratik anlamlılığa bağlı olarak hesaplanmakta ve araştırmacılara sadece eksik çalışmaların etki büyüklüğü ile birlikte kayıp çalışmaların meta-analize eklenmesiyle genel etki büyüklügünün düşeceği belirli etki büyüklüğü değerini bulma şansını da vermektedir (Üstün ve Eryılmaz, 2014: 19). Orwin yöntemi ile bulunan etki büyüklüğü düzeyini Cohen ve arkadaşlarının (2007) etki büyüklüğü sınıflandırmasında bir alt düzeye düşürebilecek etki büyüklüğü sıfır olan çalışma sayısı hesaplanır. Bu bulgu meta-analiz sonucu bulunan etki büyüklüğünün güvenirliği hakkında fikir vermektedir. PDÖ yaklaşımının, öğrencilerin fen derslerindeki akademik başarılarına etkisine ilişkin genel etki büyüklüğü değeri 0,711 ile güçlü düzeyde çıkmıştır. 0,711 etki büyüklüğü değerini, 0,01 etki büyüklüğü değerine düşürmek için etki büyüklüğü değeri sıfır olan gerekli çalışma sayısı 1192 olarak bulunmuştur.

\section{Çalışmaların Yayın Türü İle İlgili Probleme Ait Bulgular}

Akademik başarı açısından; etki büyüklüklerinin, yayın türüne göre farklılaşıp farklılaşmadığına ilişkin bulgular Tablo 3'te verilmiştir.

Tablo 3. Yayın Türüne Göre Etki Büyüklüğü Farkları

\begin{tabular}{|c|c|c|c|c|c|c|c|}
\hline Değişken & $\begin{array}{c}\text { Gruplar } \\
\text { aras1 } \\
\text { Homojenlik } \\
\text { Değeri (Qв) }\end{array}$ & $\mathbf{p}$ & $\mathbf{n}$ & ES & \multicolumn{2}{|c|}{ ES (\%95 CI) } & \multirow{2}{*}{ SE } \\
\cline { 5 - 7 } & Alt & Üst & \\
\hline $\begin{array}{c}\text { Yayın } \\
\text { Türü }\end{array}$ & 9,377 & 0,002 & & & & & \\
\hline $\begin{array}{c}\text { Yüksek } \\
\text { Lisans } \\
\text { Tezi }\end{array}$ & & & 15 & 0,466 & 0,087 & 0,844 & 0,193 \\
\hline $\begin{array}{c}\text { Doktora } \\
\text { Tezi }\end{array}$ & & & 3 & 1,901 & 1,064 & 2,739 & 0,427 \\
\hline
\end{tabular}

$\chi^{2}$ tablosundan \%95 anlamlılık düzeyinde bir serbestlik derecesi ile kritik değer 3,841 olarak bulunmuştur. Yayın türlerine göre oluşturulan grupların arasındaki homojenlik değeri ( $\left.Q_{B}\right)$ 9,377 olarak bulunmuştur. Gruplar arası homojenlik değerinin, kritik değerden daha büyük olmasından dolayı yayın türlerine göre oluşturulmuş gruplar arasında anlamlı bir fark bulunmuştur. 


\section{Çalışmaların Fen Bilimleri Alanları İle İlgili Probleme Ait Bulgular}

Akademik başarı açısından; etki büyüklüklerinin, fen bilimleri alanlarına göre farklılaşıp farklılaşmadığına ilişkin bulgular Tablo 4'te verilmiştir.

Tablo 4. Fen Bilimleri Alanlarına Göre Etki Büyüklüğü Farkları

\begin{tabular}{|c|c|c|c|c|c|c|c|}
\hline Değişken & $\begin{array}{c}\text { Gruplar } \\
\text { arası } \\
\end{array}$ & $\mathbf{p}$ & $\mathbf{n}$ & ES & \multicolumn{2}{|c|}{ ES (\%95 CI) } & SE \\
\cline { 5 - 7 } & $\begin{array}{c}\text { Homojenlik } \\
\text { Değeri (Qв) }\end{array}$ & & & Alt & Üst & \\
\hline Fen Alanı & 3,696 & 0,158 & & & & & \\
\hline Fizik & & & 9 & 0,380 & $-0,187$ & 0,947 & 0,289 \\
\hline Kimya & & & 7 & 1,192 & 0,560 & 1,825 & 0,323 \\
\hline Biyoloji & & & 2 & 0,467 & $-0,712$ & 1,647 & 0,602 \\
\hline
\end{tabular}

$\chi^{2}$ tablosundan \%95 anlamlllık düzeyinde iki serbestlik derecesi ile kritik değer 5,991 olarak bulunmuştur. Fen bilimleri alanlarına göre oluşturulan grupların arasındaki homojenlik değeri (Qв) 3,696 olarak bulunmuştur. Gruplar arası homojenlik değerinin, kritik değerden daha küçük olmasından dolayı fen bilimleri alanlarına göre oluşturulmuş gruplar arasında anlamlı bir fark bulunmamıştır.

\section{Çalışmalardaki Hedef Grubun Öğrenim Düzeyi İle İlgili Probleme Ait Bulgular}

Akademik başarı açısından; etki büyüklüklerinin, öğrencilerin öğrenim düzeylerine göre farklılaşıp farklılaşmadığına ilişkin bulgular Tablo 5'te verilmiştir. 
Tablo 5. Hedef Grubun Öğrenim Düzeyine Göre Etki Büyüklüğü Farkları

\begin{tabular}{|c|c|c|c|c|c|c|c|}
\hline \multirow[t]{2}{*}{ Değişken } & \multirow{2}{*}{$\begin{array}{c}\text { Gruplar } \\
\text { arası } \\
\text { Homojenlik } \\
\text { Değeri }\left(Q_{\text {в }}\right)\end{array}$} & \multirow[t]{2}{*}{$\mathbf{p}$} & \multirow[t]{2}{*}{ n } & \multirow[t]{2}{*}{ ES } & \multicolumn{2}{|c|}{ ES (\%95 CI) } & \multirow[t]{2}{*}{ SE } \\
\hline & & & & & Alt & Üst & \\
\hline $\begin{array}{c}\text { Öğrenim } \\
\text { Düzeyi }\end{array}$ & 0,996 & 0,802 & & & & & \\
\hline İlkokul & & & 1 & 0,772 & $-1,041$ & 2,586 & 0,925 \\
\hline Ortaokul & & & 9 & 0,501 & $-0,096$ & 1,118 & 0,310 \\
\hline Lise & & & 2 & 0,710 & $-0,573$ & 1,192 & 0,654 \\
\hline Üniversite & & & 6 & 0,994 & 0,261 & 1,728 & 0,374 \\
\hline
\end{tabular}

$\chi^{2}$ tablosundan \%95 anlamlılık düzeyinde üç serbestlik derecesi ile kritik değer 7,815 olarak bulunmuştur. Öğrenim düzeyine göre oluşturulan grupların arasındaki homojenlik değeri ( $Q_{B}$ ) 0,996 olarak bulunmuştur. Gruplar arası homojenlik değerinin, kritik değerden daha küçük olmasından dolayı öğrenim düzeyine göre oluşturulmuş gruplar arasında anlamlı bir fark bulunmamıştır.

\section{Bulgular}

Çalışmaların Örneklem Büyüklüğü İle İlgili Probleme Ait

Akademik başarı açısından; etki büyüklüklerinin, örneklem büyüklüklerine göre farklılaşıp farklılaşmadığına ilişkin bulgular Tablo 6' da verilmiştir.

Tablo 6. Örneklem Büyüklüğüne Göre Etki Büyüklüğü Farkları

\begin{tabular}{|c|c|c|c|c|c|c|c|}
\hline $\begin{array}{c}\text { Değişken } \\
\text { (Öğrenci } \\
\text { Sayısı) }\end{array}$ & $\begin{array}{c}\text { Gruplar } \\
\text { arası } \\
\text { Homojenlik } \\
\text { Değeri (Qв) }\end{array}$ & $\mathbf{p}$ & $\mathbf{n}$ & $\mathbf{E S}$ & \multicolumn{2}{|c|}{ ES (\%95 CI) } & \multirow{2}{*}{ SE } \\
\cline { 5 - 7 } & & & & Alt & Üst & \\
\hline $\begin{array}{c}\text { Örneklem } \\
\text { Büyüklüğ̈̈ }\end{array}$ & 1,195 & 0,274 & & & & & \\
\hline $\mathbf{1} \leq \mathbf{N} \leq \mathbf{2 9}$ & & & 10 & 0,506 & $-0,037$ & 1,049 & 0,277 \\
\hline $\mathbf{3 0 \leq N}$ & & & 8 & 0,953 & 0,363 & 1,543 & 0,301 \\
\hline
\end{tabular}

$\chi^{2}$ tablosundan \%95 anlamlllık düzeyinde bir serbestlik derecesi ile kritik değer 3,841 olarak bulunmuştur. Örneklem büyüklüğüne göre oluşturulan grupların arasındaki homojenlik değeri $\left(\mathrm{Q}_{в}\right)$ 1,195 olarak bulunmuştur. Gruplar arası homojenlik değerinin, kritik değerden daha 
küçük olmasından dolayı örneklem büyüklüğüne göre oluşturulmuş gruplar arasında anlamlı bir fark bulunmamıştır.

\section{Çalışmaların Uygulama Süresi İle İlgili Probleme Ait Bulgular}

Akademik başarı açısından; etki büyüklüklerinin, uygulama sürelerine göre farklılaşıp farklılaşmadığına ilişkin bulgular Tablo 7'de verilmiştir.

Tablo 7. Uygulama Süresine Göre Etki Büyüklüğü Farkları

\begin{tabular}{|c|c|c|c|c|c|c|c|}
\hline $\begin{array}{c}\text { Değişken } \\
\text { (Ders } \\
\text { saati) }\end{array}$ & $\begin{array}{c}\text { Gruplar } \\
\text { aras1 } \\
\text { Homojenlik } \\
\text { Değeri (Qв) }\end{array}$ & $\mathbf{p}$ & $\mathbf{n}$ & $\mathbf{E S}$ & \multicolumn{2}{|c|}{ ES (\%95 CI) } & \multirow{2}{*}{ SE } \\
\cline { 5 - 7 } & & & & Alt & Üst & \\
\hline $\begin{array}{c}\text { Uygulama } \\
\text { Süresi }\end{array}$ & 2,030 & 0,154 & & & & & \\
\hline $\mathbf{1 \leq s \leq 1 9}$ & & & 11 & 0,936 & 0,440 & 1,433 & 0,253 \\
\hline $\mathbf{2 0 \leq s}$ & & & 7 & 0,359 & $-0,260$ & 0,979 & 0,316 \\
\hline
\end{tabular}

$\chi^{2}$ tablosundan \%95 anlamlılık düzeyinde bir serbestlik derecesi ile kritik değer 3,841 olarak bulunmuştur. Uygulama süresine göre oluşturulan grupların arasındaki homojenlik değeri $\left(\mathrm{Q}_{\mathrm{B}}\right)$ 2,030 olarak bulunmuştur. Gruplar arası homojenlik değerinin, kritik değerden daha küçük olmasından dolayı uygulama süresine göre oluşturulmuş gruplar arasında anlamlı bir fark bulunmamıştır.

\section{Tartışma, Sonuç ve Öneriler}

Bu çalışmanın amacı; PDÖ yaklaşımının, öğrencilerin fen derslerine yönelik tutumlarına etkisini meta-analiz yöntemiyle belirlemektir. Bunun için literatür taraması yapılarak yurtiçi lisansüstü tezler incelenmiştir. PDÖ yaklaşımının öğrencilerin fen derslerine yönelik tutumlarına etkisi ile ilgili dâhil edilme ölçütlerine uygun toplam 18 adet çalışma meta-analiz çalışmasına dâhil edilmiştir.

Araştırmanın birinci sorusu "Probleme dayalı öğrenme yaklaşımı, öğrencilerin fen derslerine yönelik tutumları üzerinde pozitif bir etkiye sahip midir?" şeklindedir. Araştırmaya dâhil edilen çalışmaların sabit etkiler modeline göre homojenlik değeri ki-kare tablosunda \%95 anlamlılık düzeyinde on yedi serbestlik derecesi kritik değerini aştığı görülmüştür. Bu nedenle çalışmaların etki büyüklügünü hesaplamak için rastgele etkiler modeli kullanılmıştır. Rastgele etkiler modeline göre çalışmaların genel etki büyüklügü değeri $\mathrm{ES}=0,711$ (\%95 CI, SE=0,200) ile Cohen ve arkadaşlarının 
Sosyal Bilimler Dergisi 67

(2007) etki büyüklüğü sınıflandırmasına göre orta düzeyde bir etkiye sahiptir. PDÖ yaklaşımının, öğrencilerin fen derslerine yönelik tutumuna etkisini tespit etmek amacıyla yapılan meta-analiz çalışması sonucunda PDÖ yaklaşımının geleneksel öğrenme yöntemlerine göre öğrencilerin fen derslerine yönelik tutumlarında pozitif etkisi olduğu belirlenmiştir.

Çalışmaların etki büyüklüklerine bakıldığında en küçük etki büyüklüğü değerinin -0,241, en yüksek etki büyüklüğü değerinin ise 4,089 olduğu görülmüştür. Etki büyüklüklerinin normal dağılım grafiğine bakıldığında normal dağılıma uymayan çalışmanın olmadığı görülmektedir. Bu nedenle meta-analiz çalışmasından herhangi bir çalışmanın çıarılmasına gerek duyulmamıştır. Çalışmaların etki büyüklüklerinin yönüne bakıldığında 17 çalışmanın pozitif, 1 çalışmanın negatif yönlü olduğu belirlenmiştir. 17 pozitif çalışmanın 4 tanesi zayıf, 5 tanesi küçük, 3 tanesi orta ve 5 tanesi güçlü etki düzeyindedir.

PDÖ yaklaşımının öğrencilerin fen derslerine yönelik tutumlarına etkisine ilişkin genel etki büyüklüğü $\mathrm{ES}=0,711$ (\%95 CI, SE=0,200) değerinin, Cohen ve arkadaşlarının (2007) etki büyüklüğü sınıflandırmasına göre orta düzeyde etkisi vardır. Orwin tarafından geliştirilen yönteme göre bu düzeyi, 0 (sıfır) etki büyüklügü değerine düşürmek için etki büyüklüğü değeri sıfır olan en az 1192 çalışma gerekmektedir. Toplam 18 çalışmanın etki büyüklüğü düzeyini sıfıra düşürmek için gerekli etki büyüklüğü değerleri sıfır olan çalışmaların sayısının fazla olması meta-analiz sonuçlarının güvenilir olduğunu göstermektedir.

Araştırmanın ikinci sorusu "Probleme dayalı öğrenme yaklaşımı ile ilgili yayınların etki büyüklükleri arasında, çalışmaların yayın türüne (yüksek lisans tezi, doktora tezi) göre öğrencilerin fen derslerine yönelik tutumlarında anlamlı bir farklılık var mıdır?" şeklindedir. Bunun için 15 adet yüksek lisans tezi ve 3 adet doktora tezi meta-analize dâhil edilmiştir. Yayın türlerinin ortalama etki büyüklükleri karşılaştırıldığında en yüksek etki büyüklüğu değerinin doktora tezlerinde $(E S=1,901)$, en düşük etki büyüklüğü değerinin ise yüksek lisans tezlerinde $(E S=0,466)$ olduğu belirlenmiştir. Gruplar arası homojenlik değerine $\left(\mathrm{Q}_{\mathrm{B}}=9,377\right)$ bakıldığında bu değerin ki-kare tablosunda $\% 95$ anlamlılık düzeyinde bir serbestlik derecesi ile kritik değerden $\left(\mathrm{df}=1\right.$ için $\left.\chi^{2}(0,95)=3,841\right)$ büyük olduğu görülmüştür. $\mathrm{Bu}$ nedenle yayın türüne göre oluşturulmuş gruplar arasında anlamlı bir farklılık bulunmuştur.

Araştırmanın üçüncü sorusu "Probleme dayalı öğrenme yaklaşımı ile ilgili yayınların etki büyüklükleri arasında, öğrencilerin fen bilimleri alanlarına (fizik, kimya, biyoloji) yönelik tutumlarında anlamlı bir farklılık var mıdır?" şeklindedir. Fizik alanında 9, kimya alanında 7, biyoloji alanında 
2 çalışma bulunmaktadır. Fen bilimleri alanlarının ortalama etki büyüklükleri karşılaştırıldığında en yüksek etki büyüklügü değerinin kimya alanında $(E S=1,192)$, en düşük etki büyüklüğü değerinin ise fizik alanında $(\mathrm{ES}=0,380)$ olduğu belirlenmiştir. Gruplar arası homojenlik değerine $\left(\mathrm{Q}_{B}=3,696\right)$ bakıldığında bu değerin ki-kare tablosunda \%95 anlamlılık düzeyinde iki serbestlik derecesi ile kritik değerden $\left(\mathrm{df}=2\right.$ için $\left.\chi^{2}(0,95)=5,991\right)$ küçük olduğu görülmüştür. Bu nedenle fen bilimleri alanlarına göre oluşturulmuş gruplar arasında anlamlı bir farklılık bulunmamıştır.

Araştırmanın dördüncü sorusu "Probleme dayalı öğrenme yaklaşımı ile ilgili yayınların etki büyüklükleri arasında, öğrencilerin öğrenim düzeylerine (ilkokul, ortaokul, lise, üniversite) göre fen derslerine yönelik tutumlarında anlamlı bir farklılık var mıdır?" şeklindedir. Ortaokul düzeyinde 9 , üniversite düzeyinde 6 , lise düzeyinde 2 ve ilkokul düzeyinde 1 çalışma bulunmaktadır. Öğrencilerin öğrenim düzeylerinin ortalama etki büyüklükleri karşılaştırıldığında en yüksek etki büyüklüğü değerinin üniversite düzeyinde (ES=0,994), en düşük etki büyüklüğü değerinin ise ortaokul düzeyinde $(E S=0,501)$ olduğu belirlenmiştir. Gruplar arası homojenlik değerine $\left(\mathrm{Q}_{\mathrm{B}}=0,966\right)$ bakıldığında bu değerin ki-kare tablosunda \%95 anlamlılık düzeyinde üç serbestlik derecesi ile kritik değerden ( $\mathrm{df}=3$ için $\left.\chi^{2}(0,95)=7,815\right)$ küçük olduğu görülmüştür. Bu nedenle öğrencilerin öğrenim düzeylerine göre oluşturulmuş gruplar arasında anlamlı bir farklılık bulunmamıştır.

Araştırmanın beşinci sorusu "Probleme dayalı öğrenme yaklaşımı ile ilgili yayınların etki büyüklükleri arasında, çalışmalardaki deney grubunun örneklem büyüklüğüne (1-29 öğrenci, 30 ve üstü öğrenci) göre öğrencilerin fen derslerine yönelik tutumlarında anlamlı bir farklılık var mıdır?" şeklindedir. "1 ile 29 arası" öğrenci sayısının bulunduğu 10, "30 ve üstü" öğrenci sayısının bulunduğu 8 çalışma bulunmaktadır. Deney grubunun örneklem büyüklüklerinin ortalama etki büyüklükleri karşılaştırıldığında en yüksek etki büyüklüğü değerinin "30 ve üstü" öğrenci sayısının bulunduğu çalışmalarda $(E S=0,953)$, en düşük etki büyüklüğü değerinin ise " 1 ile 29 arası" öğrenci sayısının bulunduğu çalışmalarda $(E S=0,506)$ olduğu belirlenmiştir. Gruplar arası homojenlik değerine $\left(\mathrm{Q}_{B}=1,195\right)$ bakıldığında bu değerin ki-kare tablosunda \%95 anlamlılık düzeyinde bir serbestlik derecesi ile kritik değerden ( $\mathrm{df}=1$ için $\left.\chi^{2}(0,95)=3,841\right)$ küçük olduğu görülmüştür. Bu nedenle öğrencilerin öğrenim düzeylerine göre oluşturulmuş gruplar arasında anlamlı bir farklılık bulunmamıştır.

Araştırmanın altıncı sorusu "Probleme dayalı öğrenme yaklaşımı ile ilgili yayınların etki büyüklükleri arasında, çalışmalardaki uygulama 
Sosyal Bilimler Dergisi 69

süresine (1-19 saat, 20 ve üstü saat) göre öğrencilerin fen derslerine yönelik tutumlarında anlamlı bir farklılık var mıdır?" şeklindedir. "1 ile 19 arası" ders saati uygulanan 11, "20 ve üstü" ders saati uygulanan 7 çalışma bulunmaktadır. Uygulama sürelerinin ortalama etki büyüklükleri karşılaştırıldığında en yüksek etki büyüklüğü değerinin "1 ile 19 arası" ders saati uygulanan çalışmalarda $(E S=0,936)$, en düşük etki büyüklüğü değerinin ise "20 ve üstü" ders saati uygulanan çalışmalarda $(E S=0,359)$ olduğu belirlenmiştir. Gruplar arası homojenlik değerine $\left(\mathrm{Q}_{\mathrm{B}}=2,030\right)$ bakıldığında bu değerin ki-kare tablosunda $\% 95$ anlamlılık düzeyinde iki serbestlik derecesi ile kritik değerden $\left(\mathrm{df}=1\right.$ için $\left.\chi_{(0,95)}^{2}=3,841\right)$ küçük olduğu görülmüştür. $\mathrm{Bu}$ nedenle deneylerin uygulama sürelerine göre oluşturulmuş gruplar arasında anlamlı bir farklılık bulunmamıştır.

Araştırma sonuçlarına göre; PDÖ yaklaşımını, öğrencilerin fen derslere yönelik tutumlarını arttırmak için, fen bilimleri alanı olarak kimyada, öğrenim düzeyi olarak üniversitede, örneklem büyüklüğü olarak 30 ve üstü kişide ve uygulama süresinde 1 ile 19 ders saati aralığında kullanmak daha fazla etkili olmaktadır. Ayaz'ın (2015a) yaptığı çalışmada PDÖ yaklaşımının, öğrencilerin akademik başarılarını arttırmada da kimya ile 30 ve üstü kişide daha etkili olduğu görülmektedir. Bu çalışmada da doktora tezlerinin etki büyüklükleri daha yüksek çıkmıştır. Ayaz'ın (2015b) yaptığ çalışmada 5E öğrenme modelinin, öğrencilerin tutumuna etkisinde de üniversite ile 30 ve üstü kişide daha etkili olduğu belirlenmiştir. Bu çalışmada da yine doktora tezlerinin etki büyüklükleri daha yüksek çıkmıştır. Ayaz'ın (2014) yaptığı çalışmada PTÖ yaklaşımının, öğrencilerin tutumlarına etkisini arttırmada 1 ile 20 ders saati aralığında kullanmanın daha etkili olduğu belirlenmiştir. Bu çalışmada da yine doktora tezlerinin etki büyüklükleri daha yüksek çıkmıştır.

Araştırma sonuçlarına göre; PDÖ yaklaşımını, öğrencilerin fen derslerine yönelik tutumlarını arttırmak için, fen bilimleri alanı olarak fizikte, öğrenim düzeyi olarak ortaokulda, örneklem büyüklüğü olarak 1 ile 29 kişi aralı̆̆ında ve uygulama süresinde 20 ve üstü ders saatinde kullanmak daha az etkili olmaktadır.

Sonuçlar incelendiğinde, PDÖ yaklaşımının kimya alanında daha etkili olmasının nedeni, fen bilimleri alanlarının içinde en fazla problem oluşturulabilecek alanlardan biri olması olabilir. Benzer şekilde fizik alanı da öyle olmasına karşın, kimya alanına göre daha zor problemler oluşturduğundan öğrencilerin tutumlarında çok fazla etkili olmayabilir. PDÖ yaklaşımının üniversite döneminde daha etkili olmasının nedeni, öğrencilerin bu dönemde üst düzey düşünme becerilerini kullanabilmeleri nedeniyle fen derslerine yönelik tutumları olumlu yönde gelişmektedir 
(Bayrak, 2007; Driscoll, 2012; Kartal Taşoğlu, 2009; Özyalçın Oskay, 2009; Şalgam, 2009). Öğrencilerin özellikle ortaokul döneminde daha az karmaşık işlerle uğraşmaktan hoşlanması nedeniyle, problemlerin bu düzeydeki öğrenciler için daha az etkili olduğu söylenebilir. PDÖ yaklaşımının örneklem büyüklügü olarak 30 ve üstü kişide daha etkili olmasının nedeni, yöntemin küçük gruplara bölünerek uygulanması sonucu olabilir. PDÖ yaklaşımının, 1 ile 19 ders saati aralığında daha etkili olmasının nedeni, öğrencilerin sürekli problemlerle uğraşmaları olabilir. Sürekli problemlerle uğraşan öğrenciler merak duygularını tetiklemekte yetersiz kalmakta ve bunun sonucunda PDÖ etkisiz bir etkinlik haline gelebilmektedir. PDÖ yönteminin sınırlılıklarından da olan gereksiz ve fazla sürenin öğrencilerin sıkılmasına ve dolayısıyla tutumlarına olumsuz etkiye neden olabilir.

Araştırmada elde edilen sonuçlara dayalı olarak uygulayıcılara, program geliştiricilere ve de araştırmacılara yönelik aşağıdaki önerilerde bulunulabilir.

\section{Uygulayıcılara Yönelik Öneriler}

1. PDÖ yaklaşımının, öğrencilerin fen derslerine yönelik tutumlarına etkisini tespit etmek amacıyla yapılan meta-analiz çalışması sonucunda; PDÖ yaklaşımının, geleneksel öğrenme yöntemlerine göre öğrencilerin fen derslerine yönelik tutumlarında orta düzeyde pozitif etkisi olduğu belirlenmiştir. Fen bilimleri alanları öğretmenleri öğrencilerde derslere yönelik olumlu tutum geliştirmek için PDÖ yaklaşımını kullanabilirler.

2. PDÖ yaklaşımının öğrencilerin kimya alanına yönelik tutumlarına ilişkin etki büyüklüklerinin daha yüksek olduğu tespit edilmiştir. $\mathrm{Bu}$ nedenle PDÖ yaklaşımı özellikle kimya alanında kullanılabilir.

3. PDÖ yaklaşımının öğrencilerin öğrenim düzeylerine göre etki büyüklüklerine bakıldığında tutumda en yüksek etki büyüklüklerinin üniversite düzeyinde olduğu tespit edilmiştir. Buna göre; PDÖ yaklaşımı, özellikle üniversite düzeyinde kullanılabilir. Diğer öğrenim düzeylerinde etkililiğini arttırmak için PDÖ farklı yöntemlerle desteklenebilir.

4. Örneklem büyüklüğü sinıflamasına göre PDÖ yaklaşımının öğrencilerin fen derslerine yönelik tutumlarına ilişkin etki büyüklüklerinde 30 ve üstü kişide daha etkili olduğu belirlenmiştir. Bu nedenle PDÖ yaklaşımı sınıfları belirlenen sınıf büyüklügünde daha fazla kullanılabilir. Etkinlikler sınıfı küçük gruplara ayırarak yapılabilir.

5. Çalışmaların uygulama süresine göre PDÖ yaklaşımının öğrencilerin fen derslerine yönelik tutumlarına ilişkin etki büyüklüklerinde 
anlamlı farklılık bulunmamıştır ancak PDÖ yaklaşımı özellikle "1 ile 19 arası" ders saatinde daha etkili olduğu bulunduğundan dolayı etkinliklerin bu saatlere uygun olarak planlanması daha yararlı olacaktır.

\section{Program Geliştiricilere Yönelik Öneriler}

1. PDÖ yaklaşımının, öğrencilerin fen derslerine yönelik tutumlarına olan pozitif etkisi nedeniyle PDÖ yaklaşımına öğretim programlarında daha fazla yer verilebilir. Özellikle kimya alanındaki çalışmaların etki büyüklüğünün yüksek çıkması nedeniyle kimya dersi öğretim programında PDÖ yaklaşımına daha fazla yer verilebilir. Fizik alanındaki etki büyüklüğü değeri diğer fen bilimleri alanlarına göre daha düşük çıkmıştır. Fizik derslerinde PDÖ yaklaşımına daha az yer verilebilir.

2. PDÖ yaklaşımının, öğrencilerin fen derslerine yönelik tutumlarını özellikle üniversite düzeyinde arttırdığı belirlenmiştir. Bu nedenle, üniversite düzeyindeki öğretim programlarında PDÖ yaklaşımına daha fazla yer verilebilir.

\section{Araştırmacılara Yönelik Öneriler}

1. Farklı etki büyüklüğü düzeylerinde çıkan çalışmalar ayrı ayrı incelenerek, bu farklılıkların ne gibi faktörlerden etkilendiği tespit edilmeye çalışılabilir.

2. PDÖ yaklaşımının, biyoloji alanında uygulanması ile ilgili daha fazla çalışma yapılabilir.

3. PDÖ yaklaşımının, öğrencilerin fen derslerine yönelik tutumlarına ilişkin etki büyüklüklerinde yayın türlerine göre anlamlı farkl1lık tespit edilmiştir. Etki büyüklüklerinin en yüksek doktora tezlerinde çıktığı görülmektedir. Bu sonucun nedeni araştırılabilir.

4. Meta-analize dâhil edilen PDÖ yaklaşımı ile ilgili çalışmaların genel olarak ortaokul ve üniversite düzeyinde yapıldığı görülmektedir. $4+4+4$ eğitim sistemindeki haliyle ilkokul ve lise düzeyinde de çalışmalar yapilabilir.

\section{Kaynakça $^{1}$}

Açıkel, C. (2009). Meta Analiz ve Kanıta Dayalı Tıptaki Yeri. Klinik Psikofarmoloji Bülteni, 19(2), 164-172.

\footnotetext{
1 * ile işaretlenmiş olan kaynaklar meta-analiz çalışmasında kullanılmış olan kaynaklardir.
} 
Akçil, M. ve Karaağaoğlu, E. (2001). Tipta Meta-Analizi. Hacettepe Tıp Dergisi, 32(2), 184-190.

Akgöz, S., Ercan, İ., ve Kan, İ. (2004). Meta-Analizi. Uludă̆ Üniversitesi Tıp Fakültesi Dergisi, 30(2), 107 - 112.

Ayaz, M. F. (2014). Proje Tabanlı Öğrenme Yaklaşımının Öğrencilerin Fen Derslerindeki Akademik Başarılarına Ve Fen Derslerine Yönelik Tutumlarına Etkisi: Bir Meta-Analiz Çalışması. Doktora Tezi. Diyarbakır: Dicle Üniversitesi Eğitim Bilimleri Enstitüsü.

Ayaz, M. F. (2015a). Probleme Dayalı Öğrenme Yaklaşımının Öğrencilerin Fen Derslerindeki Akademik Başarılarına Etkisi: Bir Meta-Analiz Çalışması, Turkish Studies - International Periodical for the Languages, Literature and History of Turkish or Turkic, 10(3), 139-160, ISSN: 1308DOI Number: http://dx.doi.org/10.7827/TurkishStudies.7664.

Ayaz, M. F. (2015b). 5E öğrenme modelinin öğrencilerin derslere yönelik tutumlarına etkisi: Bir meta-analiz çalışması. Electronic Journal of Education Sciences, 4(7), 29-50.

Bağcı Kılıç, G. (2001). Oluşturmacı Fen Öğretimi. Kuram ve Uygulamada Eğitim Bilimleri Dergisi, 7-29.

*Bayrak, R. (2007). Probleme Dayalı Öğrenme Yaklaşımı ile Katılar Konusunun Öğretimi. Doktora Tezi. Erzurum: Atatürk Üniversitesi Fen Bilimleri Enstitüsü.

*Bayram, A. (2010). Probleme Dayalı Öğrenme Yönteminin İlköğretim 5. Simıf Öğrencilerinin Fen ve Teknoloji Dersi "Isı ve Sicaklı" Konusunda Sahip Oldukları Kavram Yanılgılarını Gidermede Etkisi. Yüksek Lisans Tezi. Konya: Selçuk Üniversitesi Eğitim Bilimleri Enstitüsü.

*Benli, E. (2010). Probleme Dayalı Öğrenmenin Fen Bilgisi Öğretmen Adaylarının Akademik Başarılarına, Bilgilerin Kalıcılı̆̆ına ve Fene Karşı Tutumlarına Etkilerinin Araştırllması. Yüksek Lisans Tezi. Ankara: Gazi Üniversitesi Eğitim Bilimleri Enstitüsü.

Borenstein, M., Hedges, L.V., Higgins, J.P.T. ve Rothstein, H.R. (2009). Introduction to Meta-Analysis . United Kingdom: John Wiley and Sons, Ltd. Publication.

Borenstein, B., Hedges, L.V., Higgins, J.P.T., Rothstein, H.R. (2013). MetaAnalize Giriş. (S. Dinçer, Çev.) Ankara: Anı Yayıncılık.

Cohen, L. (1988). Statistical Power Analysis for The Behavioral Sciences. New York: Academic Press.

Cohen, L. ve Manion, L. (2001). Research Methods in Education. New York: Rotledge Falmer.

Cohen, L., Manion, L. and Morrison, K. (2007). Research Methods in Education (6th Edition). New York: Routledge. 
Sosyal Bilimler Dergisi 73

Cooper, H. (2010). Research synthesis and meta-analysis: A step-by-step approach. Thousand Oaks, CA: Sage Publications.

*Çelik, E. (2010). Fen Eğitiminde Probleme Dayalı Öğrenme Yaklaşımının Öğrencilerin Akademik Başarısına, Tutumuna, Akademik Risk Alma Düzeyine ve Kalıcllı̆̆a Etkisi. Yüksek Lisans Tezi. Ankara: Gazi Üniversitesi Eğitim Bilimleri Enstitüsü.

Driscoll, P. M. (2012). Öğretim Süreçleri ve Öğrenme Psikolojisi. (Çev. Ömer F. Tutkun, Seçil Okay ve Evrim Şahin). Ankara: Anı Yayıncılık.

Erdem, M. ve Akkoyunlu, B. (2002). İlkögretim Sosyal Bilgiler Dersi Kapsamında Beşinci Sınıf Öğrencileriyle Yürütülen Ekiple Proje Tabanlı Öğrenme Üzerine Bir Çalışma. Ilköğretim Online, 1(1), 2-11.

Ergene, T. (1999). Effectiveness of test anxiety reduction programs: A metaanalysis review. Doktora tezi. Ohio: Ohio Üniversitesi.

Glass, G. (1977). Integrating Findings: The Meta Analysis of Research. Review of Research in Education, 351-379.

Gökmen, C. (2003). Fen Liselerinde Yapılan Proje Çalışmalarının, Öğrenci Tutumları ve Öğretim Görüşleri İle Değerlendirilmesi. Yayımlanmamıs Yüksek Lisans Tezi. Ankara: Gazi Üniversitesi Eğitim Bilimleri Enstitüsü.

Gündoğdu, H. İ. (2013). Proje Nedir ve Nasıl Hazırlanır? İzmir: Altın Nokta Yayınları.

${ }^{*}$ Güneş, C. (2006). Endokrin Sistemleri Ünitesinde Problem Çözmeye Dayalı Öğretimin Akademik Başarıya ve Tutuma Etkisinin Araştırılması. Yüksek Lisans Tezi. Ankara: Gazi Üniversitesi Eğitim Bilimleri Enstitüsü.

Hedges, L.V. and Olkin, I. (1985). Statistical Methods for Meta-analysis. New York: Academic Press.

Huffcutt, A. (2002). Research Perspectives on Meta Analysis. S. G. Rogelberg içinde, Handbook Of Research Methods In Industrial And Organizational Psychology (s. 198-215). Oxford: Blackwell Publishers Ltd.

Hunter, J.E. and Schmidt, F.L. (1990). Methods of Meta-Analysis: Correcting Error and Bias in Research Findings. London: Sage Publications.

İnel, D. (2009). Fen ve Teknoloji Dersinde Probleme Dayalı Öğrenme Yöntemi Kullanımının Öğrencilerin Kavramları Yapılandırma Düzeyleri, Akademik Başarıları Ve Sorgulayıcı Öğrenme Becerileri Algıları Üzerindeki Etkileri. Yüksek Lisans Tezi. İzmir: Dokuz Eylül Üniversitesi Eğitim Bilimleri Enstitüsü.

*Kanlı, E. (2008). Fen ve Teknoloji Öğretiminde Probleme Dayal Öğrenmenin Üstün ve Normal Zihin Düzeyindeki Öğrencilerin Erişi, Yaratıcı Düşünme ve Motivasyon Düzeylerine Etkisi. Yüksek Lisans Tezi. İstanbul: İstanbul Üniversitesi Sosyal Bilimler Enstitüsü. 
Karasar, N. (2005). Bilimsel Araştırma Yöntemi. Ankara: Nobel Yayın Dağıtım.

*Kartal Taşoğlu, A. (2009). Fizik Ĕ̆itiminde Probleme Dayalı Öğrenmenin Öğrencilerin Başarılarına, Bilimsel Süreç Becerilerine ve Problem Çözme Tutumlarına Etkisi. Yüksek Lisans Tezi. İzmir: Dokuz Eylül Üniversitesi Eğitim Bilimleri Enstitüsü.

*Korucu, E. N. (2007). Probleme Dayalı Öğretim ve İşbirlikli Öğrenme Yöntemlerinin İlköğretim Öğrencilerinin Başarıları Üzerine Etkileri. Yüksek Lisans Tezi. Konya: Selçuk Üniversitesi Fen Bilimleri Enstitüsü.

*Kuşdemir, M. (2010). Probleme Dayalı Öğrenmenin Öğrencilerin Başarı, Tutum ve Motivasyonlarma Etkisinin Incelenmesi. Yüksek Lisans Tezi. Hatay: Mustafa Kemal Üniversitesi.

Kemertaş, İ. (2003). Öğretimde Planlama ve Değerlendirme. İstanbul: Birsen Yayınevi.

Lipsey, M.W. and Wilson, D.B. (2001). Practical Meta-Analysis. Beverly Hills, CA: Sage Publications.

MEB. (2005). Fen ve Teknoloji Dersi 4-5. Simıflar Öğretim Programı ve Kılavuzu. Ankara: MEB.

Miles, M. B. and Huberman, A. M. (2002). The Qualitative Researcher's Companion. California: Sage Publications.

*Moralar, A. (2012). Fen Eğitiminde Probleme Dayalı Öğrenme Yaklaşımının Akademik Başarı, Tutum ve Motivasyona Etkisi. Yüksek Lisans Tezi. Edirne: Trakya Üniversitesi Fen Bilimleri Enstitüsü.

Özcan, Ş. (2008). Eğitim Yöneticisinin Cinsiyet ve Hizmetiçi Eğitim Durumunun Göreve Etkisi:Bir Meta Analitik Etki Analizi. Doktora Tezi. İstanbul: Marmara Üniversitesi Eğitim Bilimleri Enstitüsü.

*Özyalçın Oskay, Ö. (2007). Kimya Ĕ̆itiminde Teknoloji Destekli Probleme Dayalı Öğrenme Etkinlikleri. Doktora Tezi. Ankara: Hacettepe Üniversitesi Fen Bilimleri Enstitüsü.

Petticrew, M. ve Roberts, H. (2006). Systematic reviews in the social sciences. MA-USA: Blackwell Publishers Ltd.

Rosenthal, R. (1991). Meta- Analytic Procedures for Social Research. Beverly Hills, CA: Sage Publications.

Schulze, R. (2004). Meta-Analysis A Comparison of Approaches. Göttingen: Hogrefe And Huber Publishers.

Senemoğlu, N. (2010). Gelişim Öğrenme ve Öğretim. Ankara: Pegem Akademi. Soylu, H. (2004). Fen Öğretiminde Yeni Yaklaşımlar. Ankara: Nobel Yayınları.

Sönmez, D. ve Lee, H. (2003). Problem-Based Learning in Science. Mathematics and Environmental Education. 
Sosyal Bilimler Dergisi 75

Staver, J.R. ve Shroyer., M.G. (2002). Teaching Elementary Teachers How to Use the Learning Cycle for Guided Inquiry Instruction in Science. Center for Science Education. Kansas State University.

*Şalgam, E. (2009). Fizik Eğitiminde Probleme Dayalı Öğrenme Yönteminin Öğrencilerin Akademik Başarılarına ve Tutumlarına Etkisi. Yüksek Lisans Tezi. İzmir: Dokuz Eylül Üniversitesi Eğitim Bilimleri Enstitüsü.

*Tavukcu, K. (2006). Fen Bilgisi Dersinde Probleme Dayalı Öğrenmenin Öğrenme Ürünlerine Etkisi. Yüksek Lisans Tezi. Zonguldak: Zonguldak Karaelmas Üniversitesi Sosyal Bilimler Enstitüsü.

Topsakal, S. (2005). Fen ve Teknoloji Öğretimi. Ankara: Nobel Yayınları.

*Tosun, C. (2010). Probleme Dayalı Ö̆grenme Yönteminin Çözeltiler ve Fiziksel Özellikleri Konusunun Anlaşılmasına Etkisi. Doktora Tezi. Erzurum: Atatürk Üniversitesi Fen Bilimleri Enstitüsü.

Uden, L. ve Beaumont, C. (2006). Techonology and Problem-Based Learning. London: Information Science Publishing.

Ünal, F. (2005). Yaratıcılığın Geliştirilmesi. Öğretmen Dünyası Dergisi, 303312.

Wolf, F. (1986). Meta-Analysis Quantitative Methods for Research Synthesis. Beverly Hills, CA: Sage Publications.

Yıldırım, A. ve Şimşek, H. (2011). Sosyal Bilimlerde Nitel Araştırma Yöntemleri. Ankara: Seçkin Yayınevi.

*Yıldırım, H. (2011). Probleme Dayalı Öğrenme ve Proje Tabanlı Öğrenme Yöntemlerinin Illköğretim Öğrencilerinin Başarılarına ve Tutumlarına Etkisi. Yüksek Lisans Tezi. Konya: Selçuk Üniversitesi Eğitim Bilimleri Enstitüsü.

*Yıldız, N. (2010). Fen Eğitiminde Probleme Dayalı Öğrenme Senaryolarının Çözümünde Deney Uygulamalarını Öğrencilerin Başarısına, Tutumuna ve Bilimsel Süreç Becerilerine Etkisi. Yüksek Lisans Tezi. İstanbul: Marmara Üniversitesi Eğitim Bilimleri Enstitüsü.

*Yurd, M. (2007). Ilköğretim 5. Sinıf Fen ve Teknoloji Dersinde Probleme Dayalı Öğrenme Yöntemi ile Bil-İste-Öğren Stratejisi Kullanılarak Geliştirilen Bilİste-Örnekle-Öğgren Stratejisinin Öğrencilerin Kavram Yanılgılarının Giderilmesine ve Derse Karşı Tutumlarına Etkisi . Hatay: Mustafa Kemal Üniversitesi Sosyal Bilimler Enstitüsü. 


\section{EKLER}

\section{EK-1: KODLAMA FORMU}

1. Çalışmanın numarası:

2. Çalışmanın adi:

3. Çalışmanın yazarı/yazarları:

4. Çalışmanın yayımlandığı yıl:

5. Çalışmanın yayın türü:

6. Çalışmanın uygulandığı il:

7. Çalışmanın uygulama süresi:

8. Çalışmada kullanılan ölçeğin kim tarafından hazırlanıldı ğı:
( ) Araştırmacı
( ) Başkası

9. Dersin ad1:

10. Dersin konusu:

11. Çalışmanın uygulandığı öğrenci grubunun öğrenim düzeyi:
( ) İlkokul
( ) Ortaokul
( ) Lise
( )Yükseköğretim

12. Çalışmada probleme dayalı öğrenme yaklaşımına destek olarak başka bir yöntem kullanılmış mı?
( ) Evet
( ) Hayır

13. Çalışmadaki toplam örneklem sayısı:

14. Deney ve kontrol grupları tutum ölçeği tanımlayıcı istatistikler;

\begin{tabular}{|c|c|c|c|c|c|c|}
\hline & \multicolumn{3}{|c|}{ Deney Grubu } & \multicolumn{3}{c|}{ Kontrol Grubu } \\
\hline & $\mathrm{N}$ & $\mathrm{X}$ & $\mathrm{S}$ & $\mathrm{N}$ & $\mathrm{X}$ & $\mathrm{S}$ \\
\hline Öntest & & & & & & \\
\hline Sontest & & & & & & \\
\hline
\end{tabular}

N:Örneklem hacmi, $\quad$ X: Grubun ortalaması, S: Grubun standart sapması

15. Çalışmanın etki büyüklüğü: 